Ind. Health, 1972, 10, 1.

\title{
STUDIES ON LYSOZYMES V
}

\section{DETERMINATION OF C-TERMINAL AMINO ACID IN HUMAN MILK LYSOZYME BY TRITIUM LABELLING METHOD}

\author{
Masami KIMURA, Yoshiko KONDO and Noriko OTAKI \\ National Institute of Industrial Health, Kizuki-Sumiyoshi, Nakahara-ku, Kawasaki
}

(Received June 30, 1972)

\begin{abstract}
The C-terminal amino acid in human milk lysozyme (HML) was found to be valine by the tritium labelling method. The yield of the radioactive valine was less than that of the radioactive leucine obtained from the C-terminal amino acid of hen egg white lysozyme (EWL). The second amino acid, -Gly-, of the C-terminal chain of HML may affect the tritiation.
\end{abstract}

\section{INTRODUCTION}

The C-terminal amino acid in protein is selectively tritiated via oxazalone formation by the action of acetic anhydride and pyridine in ${ }^{3} \mathrm{H}_{2} \mathrm{O}$. The hydrolysis produces a mixture of the composed amino acids from the labelled protein. The mixture can be separated by paper-electrophoresis and -chromatography. The Cterminal amino acid is the only one to incorporate tritium as measured by a radiochromatogram scanner. This tritium labelling method has been developed by Matsuo et $a l^{1 \sim 4)}$. It has been applicable to insulin ${ }^{5)}$, aspartate aminotransferase ${ }^{6)}$, and ovine luteining hormone ${ }^{7}$.

This paper shows that valine is identified as the C-terminal amino acid in human milk lysozyme (HML) by the tritium labelling method.

\section{Materials AND Methods}

Isolation and purification of HML

The procedure is essentially the same one as reported by Kimura et $a l^{8}$. Human milk was acidified, defatted by centrifugation, and then dialysed against the distilled water. The clear supernatant, which was obtained from the dialysate by centrifugation, was mixed with $100 \mathrm{~g}$ of carboxymethylcellulose per 51 of the original milk. The wet powder of carboxymethylcellulose was previously equilibrated with $0.02 \mathrm{M}$ phosphate buffer, $\mathrm{pH}$ 6.8. The suspension was continuously stirred overnight. The carboxymethylcellulose absorbed HML was washed by the distilled water, $0.02 \mathrm{M}$ phosphate buffer, $\mathrm{pH} 6.8$, and $0.02 \mathrm{M}$ phosphate buffer, $\mathrm{pH} 6.8$, containing $0.1 \mathrm{M} \mathrm{NaCl}$, in turn. The lysozyme was desorbed by $0.02 \mathrm{M}$ phosphate 


\section{KIMURA, Y. KONDO AND N. OTAKI}

buffer, $\mathrm{pH} 6.8$, containing $0.5 \mathrm{M} \mathrm{NaCl}$. The lysozyme fractions were pooled and lyophilized. The crude lysozyme was fractionated by the gel filtration on a column of Sephadex G-50 (fine grade, $5 \times 150 \mathrm{~cm}$ ) using $1 \%$ acetic acid-1\% NaCl. The lysozyme fractions were collected and lyophilized. The protein was desalted by the gel filtration on a column of Bio Gel P-2 (200-400 mesh, $2.5 \times 40 \mathrm{~cm})$ using $1 \%$ acetic acid. The salt-free lysozyme was lyophilized. The yield was 50 to $100 \mathrm{mg}$ for 51 of the original milk. The centrifugation, dialysis and treatment with carboxymethylcellulose were carried out at $4^{\circ} \mathrm{C}$. The activity of lysozyme was measured by the method as previously reported ${ }^{9}$. It involved the measurement of the decrease in turbility of a suspension of Micrococcus lysodeikticus cells at 540 $\mathrm{m} \mu$.

\section{Enzymes}

The hen egg white lysozyme (EWL; $6 \mathrm{X}$ recrysterized) was obtained from Seikagaku Kogyo Co., Tokyo. The carboxypeptidase A was purchased from Worthington Biochem. Co., New Jersey.

Tritium water (Lot No. 600-08, $5.40 \mathrm{Ci} / \mathrm{ml}$ ) was obtained from Daiichi Kagaku Yakuhin Co., Tokyo.

\section{Tritium labelling method}

A lyophilized powder of lysozyme was tritiated under the following condition:

\begin{tabular}{|c|c|c|c|}
\hline \multirow{5}{*}{ Condition } & $\mathrm{A}$ & EWL (1.655 mg) & HML (1.490 mg) \\
\hline & \multirow[t]{3}{*}{ Reagent } & ${ }^{3} \mathrm{H}_{2} \mathrm{O}(50 \mathrm{mCi} / 0.1 \mathrm{ml})$ & $0.1 \mathrm{ml}$ \\
\hline & & Pyridine & $0.2 \mathrm{ml}$ \\
\hline & & Acetic anhydride & $0.05 \mathrm{ml}$ \\
\hline & \multicolumn{2}{|c|}{ Reaction time $\quad 1$} & $18 \mathrm{hr}$ \\
\hline \multirow{5}{*}{$\begin{array}{l}\text { Condition } \\
1 \text { st step }\end{array}$} & $\mathrm{B}$ & EWL (1.130 mg) & HML (1.365 mg) \\
\hline & \multirow[t]{3}{*}{ Reagent } & ${ }^{3} \mathrm{H}_{2} \mathrm{O}(50 \mathrm{mCi} / 0.1 \mathrm{ml})$ & $0.05 \mathrm{ml}$ \\
\hline & & Pyridine & $0.05 \mathrm{ml}$ \\
\hline & & Acetic anhydride & $0.2 \mathrm{ml}$ \\
\hline & \multicolumn{2}{|c|}{ Reaction time } & $1 \mathrm{hr}$ \\
\hline \multirow[t]{3}{*}{ 2nd step } & \multirow[t]{2}{*}{ Reagent } & Pyridine & \multirow{3}{*}{$\begin{array}{l}0.05 \mathrm{ml} \\
0.1 \mathrm{ml}\end{array}$} \\
\hline & & Acetic anhydride & \\
\hline & Reaction & time & \\
\hline \multirow[t]{2}{*}{ 3rd step } & Reagent & ${ }^{3} \mathrm{H}_{2} \mathrm{O}(50 \mathrm{mCi} / 0.1 \mathrm{ml})$ & \multirow[t]{2}{*}{$0.02 \mathrm{ml}$} \\
\hline & Reaction & me & \\
\hline
\end{tabular}

After the tritiation, the reaction mixture was lyophilized for the removal of the washable isotope.

Detection of radioactive $C$-terminal amino acid

The labelled protein was hydrolyzed in $6 \mathrm{~N} \mathrm{HCl}$ at $110^{\circ} \mathrm{C}$ for $24 \mathrm{hr}$. The hydrolysate was subjected to the high voltage paper-electrophoresis (solvent system: pyridine-acetic acid-water, $1: 10: 289, \mathrm{v} / \mathrm{v} / \mathrm{v}$, at 2,000 volts per $60 \mathrm{~cm}$ of the filter 


\section{STUDIES ON LYSOZYMES V}

paper, for $1.5 \mathrm{hr}$ ). The radioactive spots were detected by the aid of Radiochromatogram scanner (Packard Model 7201). The amino acids were eluted from the radioactive regions with $30 \%$ acetic acid. The eluate was dried. The amino acids were redissolved in a few drops of water and applied on the filter paper. They were separated by the paperchromatography with the solvent system of $n$-butanolacetic acid-water, $4 / 1 / 1, \mathrm{v} / \mathrm{v} / \mathrm{v}$. The radioactive amino acid was detected by the scanner and proved by the direct comparison with the paper chromatograms of the authentic specimens. The filter paper was the Toyo Roshi Filter Paper No. $50,60 \times 60 \mathrm{~cm}$.

Analysis of C-terminal amino acid by carboxypeptidase

Attempts to determine the C-terminal residue were made by the carboxypeptidase method of Guidotti ${ }^{10}$. The digestion mixture was $3.0 \mathrm{ml}$ of $0.02 \mathrm{M}$ ammonium carbonate containing $0.1 \mu$ mole and $0.01 \mu$ mole of the enzyme. During the incubation at $25^{\circ} \mathrm{C}$, aliquots were removed and terminated by the addition of $0.01 \mathrm{ml}$ of $6 \mathrm{~N} \mathrm{HCl}$. The digestion times were $2,6,18,24 \mathrm{hr}$. The digest was directly analyzed by use of the amino acid analyzer (Hitach Model 034).

\section{RESULTS}

The analytical results on the gel filtration with Sephadex G-50, disc electrophoresis and amino acid analysis showed that the HML obtained from this experiment was identical with that previously reported ${ }^{8)}$.

The free amino acids released from EWL and HML by the action of the carboxypeptidase $\mathrm{A}$ are shown in Table 1.

Table 1. Digestion of lysozymes with carboxypeptidase A.

\begin{tabular}{c|c|cc}
\hline Lysozyme & $\begin{array}{c}\text { Condition of digestion } \\
\text { Time (hr) }\end{array}$ & $\begin{array}{c}\text { Amino acid released } \\
\text { \% for one mole of lysozyme }\end{array}$ \\
\hline EWL & 21 & Leucine & 90 \\
HML & 21 & Null \\
HML & 21 in $4 \mathrm{M}$ urea & Null \\
CM-HML & 2 & Valine & 44 \\
& 6 & Valine & 45 \\
& 18 & Valine & 86.5 \\
& 24 & Valine & 69 \\
\hline
\end{tabular}

About one mole of leucine was released from EWL by the carboxypeptidase A. The enzyme did not digest HML at the native state. No amino acids were released from HML even in the urea solution. Only the carboxymethylated (CM-) HML, which was prepared according to the procedure of Canfield and Anfinsen ${ }^{11)}$, could be digested with the enzyme. About one mole of valine was released from $\mathrm{CM}-$ HML during the long time.

The tritium labelling analyses under the condition $\mathrm{A}$ and $\mathrm{B}$ were applied to EWL and HML. These results are presented in Table 2 and Fig. 1. 


\section{KIMURA, Y. KONDO AND N. OTAKI}
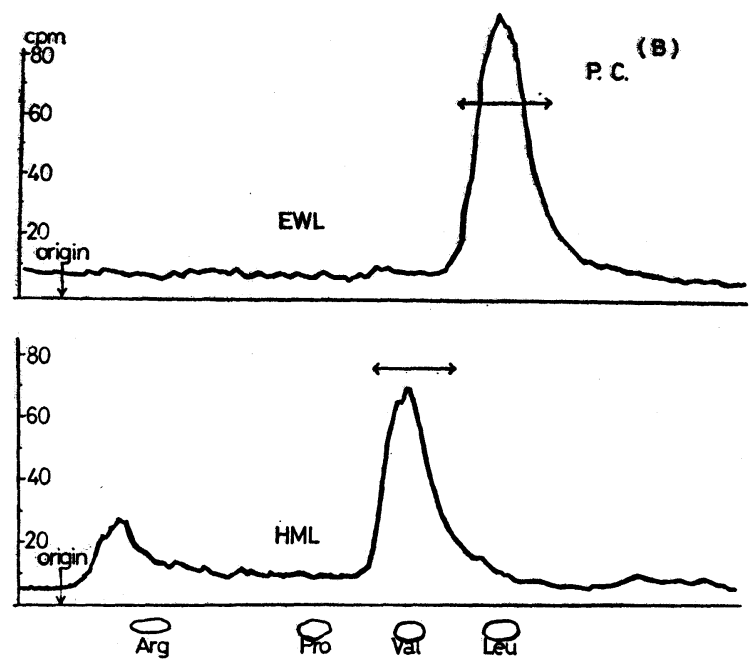

(B)
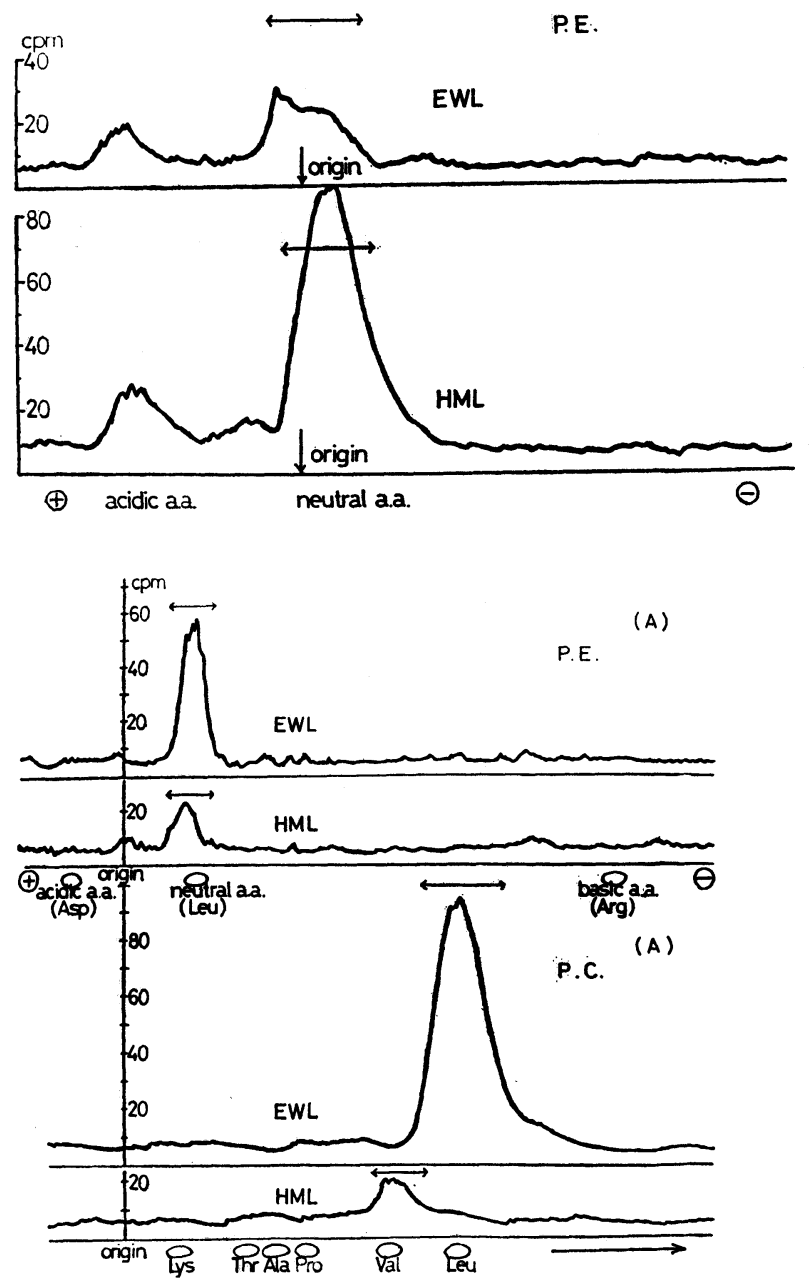

Fig. 1.

Radioactive diagrams of paperelectrophoregrams and -chromatograms for the $\mathrm{C}$-terminal amino acid analyses of lysozymes.

(A) and (B) present the condition of the tritium labelling. P.E. and P.C. indicate paperelectrophoregram and -chromatogram, respectively. Full scale is $100 \mathrm{cpm}$ and chart speed is $1 \mathrm{~cm}$ per minute. The window for the detection of radioactivity is $10 \mathrm{~mm}$ of width. Time constant is $100 \mathrm{sec}$. 


\section{STUDIES ON LYSOZYMES V}

Table 2. Recovery of radioactivity of C-terminal amino acid from hen egg white lysozyme and human milk lysozyme by tritium labelling method.

\begin{tabular}{|c|c|c|c|c|}
\hline Lysozyme & EWL & HML & EWL & HML \\
\hline Labelling condition & A & A & B & B \\
\hline Tritium water, $\mathrm{mCi}$ & 50 & 50 & 35 & 35 \\
\hline \multicolumn{5}{|l|}{ Radioactivity of eluate (cpm) } \\
\hline \multicolumn{5}{|l|}{ Paperelectrophoresis } \\
\hline Original region & 1014 & 450 & \multirow{2}{*}{34040} & \multirow{2}{*}{15975} \\
\hline Neutral amino acid region & 12786 & 1534 & & \\
\hline \multicolumn{5}{|l|}{ Paperchromatography } \\
\hline Amino acid & Leu & Val & Leu & Val $\dagger$ \\
\hline Counts & 4642 & 497 & 11275 & 5115 \\
\hline
\end{tabular}

$\dagger$ The other spot between Arg and the origin had $550 \mathrm{cpm}$.

By use of $50 \mathrm{mCi}$ of ${ }^{3} \mathrm{H}_{2} \mathrm{O}$ under the condition $\mathrm{A}$, the recovery of the radioactivity of valine from HML was one tenth of that of leucine from EWL. By use of 35 $\mathrm{mCi}$ of ${ }^{3} \mathrm{H}_{2} \mathrm{O}$ under the condition $\mathrm{B}$, the recovery of the radioactivity of valine from HML was half of that of leucine from EWL. The peak of the neutral amino acid region in the paper-electrophoregram of EWL (B) is small, because only the edge of spot might be counted. The radioactive spots in the acidic amino acid region on the paper-electrophoregrams of EWL and HML was recognized in the tritiation under the condition B. The aspartic acid residues in lysozyme might be perhaps tritiated. The radioactive spot between arginine and the origin on the paperchromatogram of HML (B) was unknown.

\section{Discussion}

Most of the chemical structure of HML have been elucidated by Jollés $e t$ al ${ }^{12}$. The amino acid sequence of the human urine lysozyme, which is isolated from the urine of patient with chronic monocytic leukemia, has been proposed by Canfield et $a l^{13)}$. Both of lysozymes may have the almost same configuration of amino acids. The C-terminal amino acid sequence of HML is reported to be -Gly-CysGly-Val. On the other hand, the C-terminal amino acid sequence of EWL is known to be -Gly-Cys-Arg-Leu ${ }^{14,15)}$.

The C-terminal amino acids of EWL and HML were analyzed in parallel. The carboxypeptidase A did not attack to HML in the native state. Even in the denatured state HML could not be digested by the enzyme, though EWL could be digested in the native state. Only CM-HML could be digested during the long time and one mole of valine was released. It seems that the $\mathrm{C}$-terminal chain of the native or denatured molecule of HML could not be accepted by the action of the carboxypeptidase A.

The C-terminal amino acid of HML was also found to be valine by the tritium labelling method. The tritiation under the condition $\mathrm{B}$ was more effective than 


\section{KIMURA, Y. KONDO AND N. OTAKI}

under the condition A. The radioactivity of valine obtained from HML was less recovered than that of leucine obtained from EWL. Even under the condition B, the radioactivity of valine was corresponding with half of the radioactivity of leucine. Matsuo ${ }^{16)}$ has demonstrated that the $\mathrm{C}$-terminal amino acid of the glycyl peptide can be merely tritiated for $50 \%$ of the corresponding amino acid. The low recovery of valine in HML may be caused by the second amino acid, -Gly-, of the C-terminal chain of HML.

\section{ACKNOWLEDGEMENT}

The authors wish to thank Dr. H. Matsuo and Dr. F. Sakiyam, University of Osaka, for their helpful discussion.

\section{REFERENCES}

1) Matsuo, H., Fujimoto, Y. and Tatsuno, T. (1966). Biochem. Biophys. Res. Commun., 22, 69.

2) Matsuo, H., Fujimoto, Y. and Tatsuno, T. (1967). Chem. Pharm. Bull. (Tokyo), 15, 716.

3) Matsuo, H., Fujimoto, Y. and Tatsuno, T. (1967). Tetrahedron Letters, 39, 3465.

4) Matsuo, H. and Matsubara, H. (1968). Proc. Soc. Exptl. Biol. Med., 129, 564.

5) Matsuo, H. (1966). Kagaku, 36, 244. (in Japanese)

6) Kagamiyama, H., Watanabe, T., Wada, H., Fujimoto, Y. and Tatsuno, T. (1968). Biochem. Biophys. Res. Commun., 32, 678.

7) Holcomb, G. N., Tames, S. A. and Ward, D. N. (1965). Biochemistry, 7, 1291.

8) Kimura, M., Otaki, N., Murayama, K., Ogawa, H. and Kobayashi, S. (1970). Ind. Health, $8,22$.

9) Kimura, M. and Otaki, N. (1970). Ind. Health, 8, 10.

10) Guidotti, G. (1960). Biochim. Biopys. Acta, 42, 177.

11) Canfield R.E. and Anfinsen, C. B. (1963). J. Biol. Chem., 238, 2684.

12) Jollés, J. and Jollés, P. (1969). Helv. Chim. Acta, 52, 2671.

13) Canfield, R. E., Kammerman, S., Sobel, J. H. and Morgan, F. J. (1971). Nature, 232, 16.

14) Jollés, J., Jauregui-Adell, J. and Jollés, P (1963). Biochim. Biophys. Acta, 78, 68; (1964). Compt Rend., 258, 3926.

15) Canfield, R.E. (1963). J. Biol. Chem., 238, 2698 ; (1965). 240, 1997.

16) Matsuo, H. and Narita, K. (1970). The 21th Symposium of Protein Structure; Abstr. 37p. The Chemical Society of Japan, Tokyo. (in Japanese). 